\title{
WARGA NEGARA MEMAHAMI DAN MELAKSANAKAN PANCASILA SEBAGAI IDEOLOGI NEGARA
}

\author{
ROZI FAHRIZAL \\ rozifahrizal1@gmail.com \\ 20220084 \\ STIE AKBP KBP PADANG
}

\section{A.PENDAHULUAN}

Pancasila adalah ideologi terbuka. Ungkapan yang sederhana tapi syarat makna ini sekarang berkembang dan mulai membudaya dalam masyarakat kita. Memang suatu konsep yang abstrak seperti "Pancasila adalah ideologi terbuka" memerlukan waktu untuk memantapkan proses pemahaman, penghayatan, pembudayaan dan pengamalannya dalam masyarakat.

Kehadiran proses itu menunjukkan bahwa roh atau jiwa dari konsep itu hidup dan berkembang. Roh itu tumbuh secara incremental, berangsur-angsur, dalam pemikiran dan praktek dalam kehidupan masyarakat sehari-hari. Ia berkembang bagaikan tanaman yang tumbuh menjadi pohon yang rindang. Agar proses pertumbuhannya wajar, sehat dan segar ia memerlukan pupuk melalui pengembangan pemikiran-pemikiran baru yang relevan dan perlu pula disirami dan disiami dengan praktek-praktek yang konkrit dalam kehidupan sehari-hari. Melalui itu semua menjadilah ia suatu konsep yang hidup dan dinamis. Kehadirannya terasa riil, komunikatif dan menjamah dalam berbagai bidang kehidupan dari satu generasi ke generasi berikutnya.

Demikianlah menurut pandangan kita, suatu ideologi terbuka mengandung semacam dinamika internal yang memungkinkannya untuk memperbaharui diri atau maknanya dari waktu ke waktu sehingga isinya tetap relevan dan komunikatif sepanjang zaman, tanpa menyimpang dari apalagi mengingkari hakekat atau jati dirinya. Pembaharuan diri (self-renewal) atau pengembangan maknanya itu bukan berarti merevisi apalagi mengganti nilai-nilai dasar yang terkandung di dalamnya. Bilamana nilai-nilai dasar itu direvisi apalagi diganti, maka ideologi 
tersebut sudah kehilangan hakekat atau jati dirinya, dan oleh karena itu meskipun secara formal ia mungkin masih ada, secara substansi ia tidak lagi hadir karena sudah direvisi atau diganti oleh nilai-nilai dasar baru.

Bagi suatu bangsa dan negara ideologi adalah wawasan, pandangan hidup atau falsafah kebangsaan dan kenegaraan. Oleh karena itu ideologi mereka menjawab secara meyakinkan pertanyaan mengapa dan untuk apa mereka menjadi satu bangsa dan mendirikan negara. Sejalan dengan itu ideologi adalah landasan dan sekaligus tujuan dalam kehidupan bermasyarakat, berbangsa dan bernegara mereka dengan berbagai dimensinya. Sebagai ideologi nasional Pancasila mengandung sifat itu.

Dari semua definisi yang dikemukakan tersebut kita mengetahui bahwa ideologi itu berintikan serangkaian nilai (norma) atau sistem nilai dasar yang bersifat menyeluruh dan mendalam yang dimiliki dan dipegang oleh suatu masyarakat atau bangsa sebagai wawasan atau pandangan hidup mereka. Melalui rangkaian atau sistem nilai dasar itu mereka mengetahui bagaimana cara yang paling baik, yaitu secara moral atau normatif dianggap benar dan adil, dalam bersikap dan bertingkah laku untuk memelihara, mempertahankan dan membangun kehidupan duniawi bersama dengan berbagai dimensinya.

Sebagaimana diketahui ada berbagai hal atau faktor yang dapat melahirkan dan mengembangkan persepsi, sikap dan tingkah laku yang tidak wajar, kurang sehat atau keliru tentang suatu ideologi. Salah satunya adalah ketika seseorang atau suatu golongan yang memiliki kekuatan dan kekuasaan memaksakan persepsinya sebagai persepsi yang paling benar. Biasanya motif atau tujuan utama dari pemaksaan persepsinya itu adalah untuk melestarikan kekuasaannya dan memenangkan kepentingannya. 
Persepsi, sikap dan tingkah laku yang tidak wajar atau keliru dapat pula terjadi dalam suasana keterbukaan atau kebebasan yang tak terbatas, apalagi kalau dirasuki pula oleh iklim saling curiga yang tajam. Dalam suasana seperti ini biasanya terjadi kecenderungan yang merangsang berbagai pihak untuk memonopoli kebenaran tentang ideologi. Hal ini bukannya hanya menyulitkan tercapainya persamaan atau keserasian persepsi, sikap dan tingkah laku, tetapi juga dapat mengembangkan nilai yang membahayakan kehidupan bersama. Peranan dan fungsi ideologi sebagai alat pemersatu dapat dilumpuhkan oleh kehadiran persaingan persepsi yang tajam dan cenderung anarkis itu. Sebagaimana yang dikemukakan oleh Sastrapratedja, ideologi memiliki kecenderungan untuk doktriner, terutama karena ia berorientasi pada tindakan atau perbuatan untuk merealisasikan nilai-nilainya.

Semakin kaya pengetahuan kita tentang Pancasila, melalui proses pengembangan pemikiran-pemikiran baru yang relevan dari masa ke masa, dapat dipakai sebagai salah satu indikator yang amat penting bahwa ideologi kita itu makin membudaya dan makin diamalkan oleh masyarakat dan bangsa kita dalam berbagai bidang kehidupan mereka sehari-hari.

Masyarakat, bangsa dan negara kita hidup dan berkembang secara dinamis seirama dengan dan sebagaimana halnya Pancasila hidup dan berkembang secara dinamis sebagai ideologi terbuka. Hal itu akan mempermantap relevansi dan kredibilitas Pancasila sebagai ideologi bagi masyarakat dan bangsa kita, dan oleh karena itu menjadikannya ideologi yang alot, kenyal dan tahan banting. Ideologi yang tak lekang oleh panas, dan tak lapuk oleh hujan, dan tak berkarat oleh perubahan jaman. Ia akan hidup dan lestari sepanjang masa. 


\section{B. PEMBAHASAN}

\section{Pengertian Pancasila}

Pancasila adalah pilar ideologi negara indonesia. Namun ini terdiri dari dua kata sanserkta : panca berarti lima dan sila berarti prinsip atau asas. Pancasila merupakan rumusan dan pedoman kehidupan berbangsa dan bernegara bagi seluruh rakyat indonesia.

a. Pengertian pancasila menurut para ahli

1. Menurut Ir. Soekarno

Pancasila merupakan jiwa bangsa indonesia secara turun-temurun yang sekiam abad lamanya terpendam bisu oleh kebudayaan barat, dengan demikian pancasila tidak saja falsafah negara, tetapi lebih luas lagi yakni falsafah bangsa indonesia.

2. Menurut Prof. Dr. Drs. Raden Mas Tumenggung Notanagoro S. H. Pancasila merupakan dasar filsafah negara indonesia, sehingga dapat diartikan kesimpulan bahwa pancasila merupakan dasar falsafah dan ideologi negara yang diharapkan menjadi pandangan hidup bangsa indonesia, sehingga dasar pemersatu, lambang persatuan dan kesatuan serta bagian pertahanan bangsa dan negara.

\section{Menurut Muhammad Yamin}

Pancasila merupakan lima dasar yang berisi pedoman atau aturan tentang tingkah laku yang penting dan baik. pancasila berasal dari kata panca yang berarti lima dan sila bearti sendi, asas, dasar atau peraturan tingkah laku yang penting dan baik.

\section{b. Dari segi Etimologi}

Istilah Pancasila dalam kehidupan Bangsa Indonesia bukanlah merupakan hal yang baru. Istilah Pancasila juga telah dikenal sejak zaman Majapahit pada abad ke-14, yaitu terdapat di dalam buku Negarakertagama karangan Empu Prapanca, dan dalam buku Sutasoma karangan 
Empu Tantular. Dalam buku Sutasoma ini istilah Pancasila di samping mempunyai arti "berbatu sendi yang lima" - berasal dari bahasa Sansekerta; Panca yang berarti lima dan sila yang berarti berbatu sendi, alas, atau dasar.

Dikatakan juga, bahwa sejak zaman Budhisme masuk ke tanah air kita, telah dikenal kata Pancasila (Panca shila) yang mempunyai arti sama sebagaimana dikemukakan Muhammad Yamin, yaitu kesusilaan yang lima. Jadi pada masa itu istilah Pancasila bukan untuk menyebut asas kenegaraan, tetapi merupakan tuntunan tingkah laku/akhlak (code of morality). Ajaran Buddha yang terdapat dalam Vinaya, yang kemudian menjadi code of morality itu, dapat dikutip sebagai berikut:

1. Panatipata Veramaniskkhapadam Samadiyami (kami berjanji untuk menghindari pembunuhan).

2. Adinnadana Veramanisikkhapadam Samadiyami (kami berjanji untuk menghindari pencurian).

3. Kamecu Micchacara Veramani sikkhapadam Samadiyami (kami berjanji untuk menghindari perzinahan).

4. Mussavada Veramani sikkhapadam Samadiyami (Kami berjanji untuk menghindari kebohongan)

5. Sura Meraya Majja Pamadattana Veramani sikkhapadam Samadiyami (kami berjanji untuk menghindari makanan dan minuman yang memabukkan dan menjadi ketagihan).

Dengan masuknya agama Buddha ke Indonesia, ajaran Buddha yang tercermin dalam istilah Pancasila berpengaruh dalam budaya kehidupan masyarakat Indonesia dan khususnya di 
Jawa sangat dikenal larangan "Ma-lima” (lima M) yaitu: Mateni (membunuh), Maling (mencuri), Madon (berzina), Main (bermain judi), dan Madat/Mabuk.

Demikianlah istilah Pancasila yang telah ada dan dikenal dalam budaya kehidupan bangsa Indonesia sejak dahulu kala dan mengandung nilai etik, sebagai aturan tingkah laku manusia yang baik dalam kehidupan bermasyarakat.

c. Dari segi Terminologi

Pada tanggal 1 Juni 1945, Ir. Soekarno kembali memperkenalkan istilah Pancasila yang telah lama dikenal dalam budaya kehidupan bangsa Indonesia untuk digunakan sebagai nama untuk dasar negara Indonesia yang akan didirikan. Lima dasar yang diusulkan pada waktu itu adalah:

1. Kebangsaan Indonesia atau nasionalisme,

2. Perikemanusiaan atau internasionalisme,

3. Mufakat atau demokrasi,

4. Kesejahteraan sosial,

5. Ketuhanan yang maha esa.

Setelah proklamasi kemerdekaan, pada tanggal 18 Agustus 1945, Panitia Persiapan Kemerdekaan Indonesia kemmudian menetapkan dan mengesahkan lima dasar negara yang rumusannya terdapat dalam Pembukaan Undang Undang Dasar 1945, bersamaan dengan disahkannya Pembukaan Undang Undang Dasar itu sendiri. Jadi secara terminologis yang dimaksud dengan Pancasila sekarang ini adalah "Nama Dasar Negara kita, Negara Republik Indonesia”, berupa lima dasar negara yang perumusannya tercantum dalam pembukaan Undang Undang Dasar 1945 yaitu:

1. Ketuhanan Yang Maha Esa. 
2. Kemanusiaan yang adil dan beradab.

3. Persatuan Indonesia.

4. Kerakyatan yang dipimpin oleh hikmat kebijaksanaan dalam permusyawaratan/perwakilan.

5. Keadilan sosial bagi seluruh rakyat Indonesia.

\section{Fungsi Pancasila}

Pada dasarnya Pancasila adalah merupakan "Dasar Negara" dan merupakan "Pandangan hidup bangsa Indonesia”. Dari kedua pengertian dasar ini kemudian dikembangkan berbagai macam predikat yang dihubungkan dengan Pancasila, mengingat fungsi Pancasila demikian luas dalam kedudukannya sebagai pedoman untuk mengatur penyelenggaraan negara dan kehidupan bangsa Indonesia.

Beberapa konsep pengertian Pancasila yang sehubungan dengan fungsi Pancasila yakni sebagai berikut:

a. Pancasila sebagai dasar negara

Pancasila sebagai Dasar Negara Republik Indonesia, sering juga disebut dengan istilah "Dasar falsafah (filsafat) Negara, Ideologi Negara, Staat Idee dan Philosofische grondslag”. Dalam pengertian ini, Pancasila dipergunakan sebagai dasar mengatur pemerintahan negara atau digunakan sebagai dasar untuk mengatur penyelenggaraan negara. Pancasila sebagai dasar negara ini memang sesuai dengan sejarah kelahirannya yang dipersiapkan sebagai dasar negara. Oleh karena itu fungsi Pancasila sebagai dasar negara adalah merupakan fungsi pokok. Penjabaran fungsi pokok Pancasila sebagai dasar negara ini dituangkan dalam Undang Undang Dasar 1945 yang merupakan tafsir resmi dari Pancasila sebagai dasar negara. 
b. Pancasila sebagai sumber dari segala sumber hukum

Pancasila sebagai sumber dari segala sumber hukum merupakan istilah yang sudah dikenal sejak adanya Ketetapan MPRS.No.XX/MPRS/1966. Penggunaan istilah ini mempunyai hubungan yang erat dengan fungsi pokok Pancasila sebagai dasar negara. Sebab mengatur dan menyeleggarkan pemerintahan dalam negara hukum diwujudkan dalam aturan-aturan hukum. Dalam tertib hukum di Indonesia terdapat susunan hirarki dari peraturan hukum/perundangan yang berlaku. Dan Pancasila merupakan sumber hukum yang tertinggi, atau disebut sebagai sumber dari segala sumber hukum.

Dari kutipan TAP. MPRS. No. XX/MPRS/1996, ditemukan bahwa yang dimaksud dengan sumber dari segala sumber hukum adalah pandangan hidup, kesadaran, dan cita-cita hukum serta cita-cita moral yang meliputi suasana kejiwaan serta watak dari rakyat Indonesia, yang dikristalisasikan dalam rumusan lima sila dari Pancasila.

Jadi Pancasila merupakan sumber nilai dan dengan nilai-nilai yang terkandung di dalamnya dibentuklah norma-norma hukum oleh negara. Norma hukum yang tercipta harus berdasarkan dan dijiwai oleh nilai-nilai etis, nilai religius, nilai kebenaran, nilai vital dan nilai materiil seperti dikandung oleh falsafah Pancasila.

Adapun sebagai perwujudan dari Pancasila sebagai sumber dari segala sumber hukum itu ialah:

1. Proklamasi Kemerdekaan 17 Agustus 1945

2. Dekrit Presiden 5 Juli 1959

3. Undang Undang Dasar Proklamasi (1945)

4. Surat Perintah 11 Maret 1966. 
c. Pancasila sebagai pandangan hidup bangsa Indonesia

Pancasila dalam hal ini dipergunakan sebagai pegangan atau petunjuk dalam kehidupan sehari-hari setiap warga negara Indonesia. Pancasila dipergunakan sebagai petunjuk arah semua kegiatan atau aktifitas hidup dan kehidupan.

Apabila memperhatikan sejarah perkembangan bangsa Indonesia, nilai-nilai yang terkandung dalam Pancasila sudah ada sejak dahulu kaladan berkembang bersamaan dengan perkembangan kehidupan bangsa Indonesia sampai sekarang. Oleh karena itu, dengan kata lain nilai-nilai tersebut merupakan falsafah hidup bangsa Indonesia. Sehingga Pancasila sebagai pandangan hidup, juga disebut sebagai falsafah hidup.

Nilai-nilai Pancasila termasuk golongan nilai kerohanian, yang mengakui adanya nilai materiil dan nilai vital secara seimbang. Hal ini terbukti dari susunan kelima silanya yang tersusun secara sistematis dan hierarkis, dimulai dari sila pertama Ketuhanan yang maha Esa sampai sila kelima keadilan sosisal bagi seluruh rakyat Indonesia. Karena itulah maka Pancasila sebagai pandangan hidup merupakan hal yang sangat fundamental/asasi bagi kekokohan dan kelangsungan hidup bangsa dan negara Indonesia.

d. Pancasila sebagai jiwa dan kepribadian bangsa Indonesia

Sebagaimana telah diuraikan di atas, jiwa Pancasila sebenarnya telah ada sejak berabadabad lamanya dalam kehidupan bangsa Indonesia dan keberadaannya bersamaan dengan adanya bangsa Indonesia. Pancasila menjadi dan memberi corak yang khas kepada bangsa Indonesia yang membedakannya dengan bangsa lain. Jiwa Pancasila telah menjadi bagian tak terpisahkan dalam kehidupan bangsa Indonesia.

Sebagai jiwa bangsa Indonesia, Pancasila (apabial dihubungkan dengan teori organis), maka Pancasila akan merupakan ruhnya dalam kehidupan bangsa Indonesia, akan menentukan 
mati hidupnya bangsa Indonesia, serta watak dan kepribadiannya. Sebagai jiwa bangsa, keberadaannya akan menentukan hidupnya bangsa, memberikan semangat, pendorong ke arah kemajuan bangsa. Inilah yang memberikan corak dan ciri khas bangsa Indonesia, sehingga merupakan jiwa dan kepribadian Indonesia.

e. Pancasila sebagai perjanjian luhur rakyat Indonesia

Pancasila yang merupakan jiwa dan kepribadian bangsa Indonesia itu ditemukan kembali setelah lama terpendam pada masa penjajahan bangsa barat. Kemudian pada saat bangsa Indonesia bangkit akan hidup sendiri sebagai bangsa yang merdeka, bangsa Indonesia menemukan kembali Pancasila. Pada saat akan mendirikan negara Republik Indonesia yang merdeka para pemimpin rakyat memusyawarahkan apa sebaiknya yang akan jadi dasar negara, kemudian ditemukanlah Pancasila. Jadi dalam pengertian ini, Pancasila sebagai hasil persetujuan bersama wakil-wakil rakyat menjelang proklamasi kemerdekaan, yaitu disetujui bersama dan disahkan pada tanggal 18 Agustus 1945.

Naskah persetujuan itu dituangkan dalam pembukaan Undang Undang Dasar 1945 oleh pembentuk negara. Karena merupakan persetujuan/kesepakatan bersama, ia merupakan perjanjian pada saat meletakkan/menetapkan negara Republik Indonesia. Oleh karena itu maka ia megikat kita bersama dan perjanjian itu untuk kita hormati dan dilaksanakan bersama. f. Pancasila sebagai tujuan yang akan dicapai oleh bangsa Indonesia Tujuan kehidupan bangsa Indonesia adalah untuk mewujudkan masyarakat adil dan Makmur berdasarkan Pancasila. Dalam pembangunan nasional dewasa ini, sebagai pembangunan manusia Indonesia seutuhnya, dan pembangunan masyarakat Indonesia seluruhnya, dirumuskan dalam Garis-garis Besar Haluan Negara, bahawa tujuan pembangunan nasional "untuk mewujudkan suatu masyarakat adil dan makmur yang merata materiil dan 
spiritual berdasarkan Pancasila di dalam wadah negara kesatuan Republik Indonesia yang merdeka, berdaulat, bersatu dan berkedaulatan rakyat dalam suasana perikehidupan bangsa yang aman, tentram, tertib dan dinamis serta dalam lingkungan pergaulan dunia yang merdeka, bersahabat, tertib dan damai". Dengan kata lain secara singkat bahwa yang hendak diwujudkan oleh bangsa Indonesia adalah "masyarakat Pancasila".

Selanjutnya Pancasila juga sering disebut sebagai alat pemersatu bangsa Indonesia. Hal ini sehubungan kenyataan bangsa Indonesia yang tinggal di berbagai daerah dan wilayah yang terdiri dari beribu pulau dengan berpuluh-puluh suku bangsa dan berbeda adat istiadatnya serat beragam kebudayaan. Dalam tata susunan masyarakat yang demikian, tepat kalua diberi landasan bersifat umum dan universal yang dapat sebanyak mungkin mencakup sebuah peri kehidupan yang berbhineka dan dapat diterima oleh semua pihak. Kenyataan telah menunjukkan bahwa dengan dasar Pancasila telah dapat menimbulkan semangat persatuan dan kesatuan bangsa dan dapat membawa keutuhan bangsa dan negara Republik Indonesia dari berbagai pergolakan dan perpecahan yang mengancam bangsa dan negara.

3.Memahami dan melaksanakan Pancasila dalam kehidupan sehari-hari

Seperti yang kita tahu, Pancasila merupakan pedoman dalam sendi-sendi kehidupan, baik dalam bermasyarakat, berbangsa, maupun bernegara. Sayangnya, tidak semua orang tahu cara menerapkan nilai-nilai dalam Pancasila dalam kehidupan sehari-hari. Supaya kita bisa mengimplementasikannya secara maksimal, berikut pemaparan seputar praktek Pancasila berdasarkan sila-silanya.

1. Ketuhanan yang Maha Esa 
Dalam sila kesatu, Pancasila memaknai akan keyakinan setiap warga negara terhadap Tuhan yang Maha Esa dan bernegara sesuai ketuhanan. Dengan kata lain, negaramelalui sila satu Pancasila telah menjamin kewajiban maupun hak masyarakat yang ingin melaksanakan keyakinan berdasarkan agama yang mereka peluk. Selain itu, sila satu juga mendorong pertumbuhan sikap toleransi umat beragama, sehingga dapat mewujudkan kehidupan harmonis dan mencegah konflik sosial.

Makna-makna sila satu Pancasila tersebut dapat kita realisasikan dengan:

- Percaya akan adanya Tuhan yang Maha Esa sesuai keyakinan dan kepercayaan yang tulus timbul dari hati;

- Menghormati para pemeluk agama lain dan melaksanakan keyakinan masing-masing tanpa harus saling mengganggu untuk menjaga kerukunan bergama dan keutuhan NKRI;

- Saling membantu dalam kehidupan dalam kehidupan beragama;

- Implementasi akhlak dari agama yang dapat membantu pembentukan karakter bangsa, karena adanya keyakinan beragama yang dilindungi negara.

2. Kemanusiaan yang Adil dan Beradab

Dalam sila kedua Pancasila, terdapat prinsip persamaan di antara kedudukan warga dalam negara dan martabat manusia yang menyimpan potensi dalam kebudayaan. Setiap warga yang tinggal di Indonesia adalah bagian dari masyarakat dunia yang mengakui manusia mempunyai kedudukan setara. Contohnya pengakuan dalam kebebasan berpendapat hingga berorganisasi yang tepat memegang teguh adab selaku bangsa dengan budaya luhur sejak dahulu kala.

Kemudian, untuk menanamkan makna-makna dalam sila kedua Pancasila, kita dapat melakukan hal-hal berikut ini:

- Mengakui adanya persamaan hak dan kewajiban serta derajat warga negara; 
- Mengukuhkan sikap saling mengasihi terhadap sesama warga negara demi membangun kehidupan harmonis nan rukun;

- Memupuk sikap tenggang rasa dan mencegah sikap tercela seperti perilaku sewenangwenang hingga pelanggaran hak terhadap hak warga negara;

- Menjunjung tinggi nilai-nilai kemanusiaan dan menghargai di antara perbedaan.

\section{Persatuan Indonesia}

Selanjutnya, kata persatuan yang terdapat dalam sila ketiga Pancasila mengandung makna persatuan bangsa dalam berbagai sendi kehidupan. Hal tersebut mencakup sosial, budaya, politik, ekonomi hingga pertahanan dan keamanan. Selain itu, sila ini juga mempunyai tujuan menumbuhkan kesadaran persatuan di antara warga negara Indonesia yang majemuk dalam sektor budaya. Dengan begitu, akan tercipta pula kebanggaan, solidaritas, kebersamaan, hingga nasionalisme tinggi.

Memaknai nilai-nilai persatuan dalam sila ketiga Pancasila akan membuat kita lebih menghormati aspek kemajemukan. Sementara untuk mempraktekan nilai-nilai tadi, kita dapat menyikapinya dengan:

- Memprioritaskan persatuan, kesatuan, dan kehidupan berbangsa di atas kepentingan golongan;

- Menghindari sikap maupun tindakan egois, sehingga mampu rela berkorban untuk bangsa dan negara secara optimal;

- Menjaga keberagaman bangsa dengan mencegah keributan maupun konflik yang dirasa kurang berfaedah; 
- Senantiasa menjunjung tinggi semboyan Bhinneka Tunggal Ika saat menjalankan kehidupan sehari-hari, misalnya dengan tidak mengotak-ngotakkan suku maupun agama demi kepentingan tertentu;

- Sanggup mencintai bangsa dan negara dengan menekan penyebab luruhnya Bhinneka Tinggal Ika dalam kehidupan sehari-hari.

4. Kerakyatan yang Dipimpin oleh Hikmat Kebijaksanaan dalam Permusyawaratan Perwakilan

Makna yang terkandung dalam sila keempat Pancasila berkaitan dengan prinsip-prinsip demokrasi yang bersumber dari nilai-nilai pendidikan karakter dan tata cara kehidupan bangsa. Demokrasi mempunyai pemahaman yang menjunjung kekuasaan berada di tangan rakyat atau kedaulatan rakyat. Hal tersebut tercermin dari pengambilan setiap keputusan yang selalu memiliki dampak terhadap masyarakat luas dan diambil melalui musyawarah hingga mencapai kemufakatan atau kesepakatan.

Untuk menciptakan makna sila keempat, kita dapat mempraktekan:

- Pengukuhan sistem mayoritas tanpa memaksakan kehendak pribadi;

- Memprioritaskan keputusan yang berkaitan dengan kehidupan masyarakat luas;

- Melaksanakan setiap keputusan yang ditentukan dari hasil musyawarah;

- Bertanggung jawab atas setiap keputusan secara moral kepada Tuhan yang Maha Esa.

5. Keadilan Sosial bagi Seluruh Rakyat Indonesia

Dalam sila kelima, terdapat makna yang membahas seputar keadilan yang merupakan hak asasi setiap warga. Selain itu, negara menjamin hal tersebut dan sudah mencakup seluruh aspek kehidupan — baik secara material maupun spiritual tanpa terkecuali. Keadilan dalam aspek sosial sangat berdampak pada kehidupan bermasyarakat yang akan membantu terbentuknya kesetaraan. 
Misalnya, berlaku adil tanpa pilih kasih sesuai status sosial dan mempunyai kepribadian arif nan bijaksana.

Kita dapat menerapkan makna dan nilai sila kelima Pancasila melalui hal-hal berikut ini:

- Menanamkan rasa kekeluargaan dan gotong-royong di tengah kehidupan bermasyarakat;

- Menjaga stabilitas di antara hak dan kewajiban dalam kehidupan sosial. Misalnya dengan melakukan kewajiban kita sebagai bagian masyarakat untuk memastikan keamanan di lingkungan sekitar;

- Tidak memaksakan opini atau opini terhadap sebuah peristiwa. Menekan egosime pun sangat diperlukan saat berhadapan dengan kepentingan kelompok;

- Mengawasi dan membantu orang lain yang sedang kesusahan;

- Menjauhi sikap-sikap tercela seperti tidak merampas hak orang lain yang selama ini menjadi penyebab konflik sosial di Indonesia;

- Mendalami konsep berbagi untuk menciptakan keadilan.

\section{PENUTUP}

> Pancasila dalam segi etimologi artinya terdapat di dalam buku Negarakertagama karangan Empu Prapanca, dan dalam buku Sutasoma karangan Empu Tantular. Dalam buku Sutasoma ini istilah Pancasila di samping mempunyai arti "berbatu sendi yang lima" - berasal dari bahasa Sansekerta; Panca yang berarti lima dan sila yang berarti berbatu sendi, alas, atau dasar.

$>$ Pancasila dalam segi terminology adalah "Nama Dasar Negara kita, Negara Republik Indonesia”, berupa lima dasar negara yang perumusannya tercantum dalam pembukaan Undang Undang Dasar 1945. 
$>$ Fungsi dari Pancasila adalah sebagai dasar negara, sebagai sumber dari segala sumber hokum, sebagai pandangan hidup bangsa Indonesia, sebagai jiwa dan kepribadian bangsa Indonesia, sebagai perjanjian luhur rakyat Indonesia, dan sebagai tujuan yang akan dicapai oleh bangsa Indonesia.

Kita sebagai warga negara Indonesia haruslah mengerti, memahami dan mengamalkan nilainilai Pancasila agar terciptanya suatu kehidupan berbangsa yang harmonis. Sehingga walaupun terjadi kekacauan, kita dapat mengatasinya tanpa terjadinya perpecahan. Karena di dalam ajaran Pancasila, dalam pengambilan suatu keputusan juga harus dengan bermusyawarah sesuai dengan sila ke-4.

Dalam kehidupan sehari-hari, hendaklah kita selalu mengamalkan nilai-nilai Pancasila, misalnya seperti menghormati orang yang beragama, ras, atau memiliki adat/budaya yang berbeda dari diri kita. Karena perbedaan itu jangan kita jadikan sebagai hal yang memecah-belah kita semua, namun justru harus kita jadikan sebagai hal yang memperkuat persatuan antar warga negara. Sesuai dengan istilah Bhinneka Tunggal Ika, berbeda-beda tapi tetap satu.

\section{DAFTAR PUSTAKA}

Darmini Roza dan Laurensius Arliman S Peran Pemerintah Daerah Di Dalam Melindungi Hak Anak Di Indonesia, Masalah-Masalah Hukum, Volume 47, Nomor 1, 2018.

Laurensius Arliman S, Komnas HAM dan Perlindungan Anak Pelaku Tindak Pidana, Deepublish, Yogyakarta, 2015.

Laurensius Arliman S, Penguatan Perlindungan Anak Dari Tindakan Human Trafficking Di Daerah Perbatasan Indonesia, Jurnal Selat, Volume 4,Nomor 1, 2016.

Laurensius Arliman S,Problematika Dan Solusi Pemenuhan Perlindungan Hak Anak Sebagai Tersangka Tindak Pidana Di Satlantas Polresta Pariaman, Justicia Islamica, Volume 13,Nomor 2, 2016. 
Laurensius Arliman S, Pelaksanaan Perlindungan Anak Yang Tereksploitasi Secara Ekonomi Oleh Pemerintah Kota Padang, Veritas et Justitia, Volume 2, Nomor 1, 2016.

Laurensius Arliman S, Kedudukan Ketetapan MPR Dalam Hierarki Peraturan PerundangUndangan Di Indonesia,Lex Jurnalica, Volume 13, Nomor 3, 2016.

Laurensius Arliman S,Komnas Perempuan Sebagai State Auxialiary Bodies Dalam Penegakan Ham Perempuan Indonesia, Justicia Islamica, Volume 14, Nomor 2, 2017.

Laurensius Arliman S, Peranan Pers Untuk Mewujudkan Perlindungan Anak Berkelanjutan Di Indonesia, Jurnal Ilmu Hukum Tambun Bungai, Volume 2, Nomor 2, 2017.

Laurensius Arliman S,Mewujudkan Penegakan Hukum Yang Baik Untuk Mewujudkan Indonesia Sebagai Negara Hukum, Jurnal Hukum Doctrinal, Volume 2, Nomor 2, 2017.

Laurensius Arliman S, Participation Non-Governmental Organization In Protecting Child Rights In The Area Of Social Conflict, The 1st Ushuluddin and Islamic Thought International Conference (Usicon), Volume 1, 2017.

Laurensius Arliman S, Partisipasi Masyarakat Dalam Pembentukan Perundang-Undangan Untuk Mewujudkan Negara Kesejahteraan Indonesia, Jurnal Politik Pemerintahan Dharma Praja, Volume 10, Nomor 1, 2017, https://doi.org/10.33701/jppdp.v10i1.379.

Laurensius Arliman S,Peran Komisi Perlindungan Anak Indonesia Untuk Mewujudkan Perlindungan Anak, Jurnal Respublica Volume 17, Nomor2, 2018.

Laurensius Arliman S, Menjerat Pelaku Penyuruh Pengrusakan Barang Milik Orang Lain Dengan Mempertimbangkan Asas Fungsi Sosial, Jurnal Gagasan Hukum, Volume 1, Nomor 1, 2019.

Laurensius Arliman S, Ilmu Perundang-Undangan Yang Baik Untuk Negara Indonesia, Deepublish, Yogyakarta, 2019.

Laurensius Arliman S, Isdal Veri, Gustiwarni, Elfitrayenti, Ade Sakurawati, Yasri, Pengaruh Karakteristik Individu, Perlindungan Hak Perempuan Terhadap Kualitas Pelayanan Komnas Perempuan Dengan Kompetensi Sumber Daya Manusia Sebagai Variabel Mediasi, Jurnal Menara Ekonomi: Penelitian dan Kajian Ilmiah Bidang Ekonomi, Volume 6, Nomor 2, 2020.

Laurensius Arliman S, Pendidikan Kewarganegaraan, Deepublish, Yogyakarta, 2020.

Laurensius Arliman S,Makna Keuangan Negara Dalam Pasal Pasal 23 E Undang-Undang Dasar 1945, Jurnal Lex Librum, Volume 6, Nomor 2 Juni 2020, http://dx.doi.org/10.46839/1ljih.v6i2.151. 
Laurensius Arliman S, Kedudukan Lembaga Negara Independen Di Indonesia Untuk Mencapai Tujuan Negara Hukum, Kertha SemayaJournal Ilmu Hukum, Volume 8, Nomor 7, 2020.

Laurensius Arliman S, Pelaksanaan Assesment Oleh Polres Kepulauan Mentawai Sebagai Bentuk Pelaksanaan Rehabilitasi Bagi Pecandu Dan Korban Penyalahgunaan Narkotika, Jurnal Muhakkamah, Volume 5, Nomor 1, 2020.

Laurensius Arliman S, Aswandi Aswandi, Firgi Nurdiansyah, Laxmy Defilah, Nova Sari Yudistia, Ni Putu Eka, Viona Putri, Zakia Zakia, Ernita Arief, Prinsip, Mekanisme Dan Bentuk Pelayanan Informasi Kepada Publik Oleh Direktorat Jenderal Pajak, Volume 17, No Nomor, 2020.

Larensius Arliman S, Koordinasi PT. Pegadaian (Persero) Dengan Direktorat Reserse Narkoba Polda Sumbar Dalam Penimbangan Barang Bukti Penyalahgunaan Narkotika, UIR Law Review, Volume 4, Nomor 2, 2020, https://doi.org/10.25299/uirlrev.2020.vol4(1).3779.

Laurensius Arliman S, Tantangan Pendidikan Kewarganegaraan Pada Revolusi 4.0, Ensiklopedia Sosial Review, Volume 2, Nomor 3, 2020.

Muhammad Afif dan Laurensius Arliman S, Protection Of Children's Rights Of The Islamic And Constitutional Law Perspective Of The Republic Of Indonesia, Proceeding: Internasional Conference On Humanity, Law And Sharia (Ichlash), Volume1, Nomor 2, 2020.

Otong Rosadi danLaurensius Arliman S, Urgensi Pengaturan Badan Pembinaan Idelogi Pancasila Berdasarkan Undang-Undang Sebagai State Auxiliary Bodies yang Merawat Pancasila dalam Perspektif Hak Asasi Manusia, Prosiding Konferensi Nasional Hak Asasi Manusia, Kebudayaan dan Tujuan Pembangunan Berkelanjutan Indonesia pada Masa Pandemi Covid-19: Tantangan untuk Keilmuan Hukum dan Sosial Volume 1, Universitas Pancasila, Jakarta, 2020. 